Article

\title{
Energy Savings Associated with the Use of Fly Ash and Nanoadditives in the Cement Composition
}

\author{
Grzegorz Ludwik Golewski \\ Department of Structural Engineering, Faculty of Civil Engineering and Architecture, \\ Lublin University of Technology, Nadbystrzycka 40 str., 20-618 Lublin, Poland; g.golewski@pollub.pl; \\ Tel.: +48-81-538-4394
}

Received: 26 March 2020; Accepted: 27 April 2020; Published: 1 May 2020

\begin{abstract}
The paper presented herein investigates the effects of using supplementary cementitious materials (SCMs) in quaternary mixtures on the compressive strength and splitting tensile strength of plain concrete. In addition, environmental benefits resulting from the proposed solutions were analysed. A total of four concrete mixtures were designed, having a constant water/binder ratio of 0.4 and total binder content of $352 \mathrm{~kg} / \mathrm{m}^{3}$. The control mixture only contained ordinary Portland cement (OPC) as binder, whereas others incorporated quaternary mixtures of: OPC, fly ash (FA), silica fume (SF), and nanosilica (nS). Based on the obtained test results, it was found that concretes made on quaternary binders containing nanoadditives have very favorable mechanical parameters. The quaternary concrete containing: $80 \%$ OPC, $5 \%$ FA, $10 \%$ SF, and $5 \%$ nS have shown the best results in terms of good compressive strength and splitting tensile strength, whereas the worst mechanical parameters were characterized by concrete with more content of FA additive in the concrete mix, i.e., $15 \%$. Moreover, the results of compressive strength and splitting tensile strength are qualitatively convergent. Furthermore, reducing the amount of OPC in the composition of the concrete mix in quaternary concretes causes environmental benefits associated with the reduction of: raw materials that are required for burning clinker, electricity, and heat energy in the production of cement.
\end{abstract}

Keywords: quaternary concrete; energy saving; fly ash (FA); silica fume (SF); nanosilica (nS); mechanical parameters; environmental benefits; cement manufacturing process

\section{Introduction}

Concrete is a common building material that was already used in the Neolithic [1], while the oldest known concrete is the flooring discovered in 1985 in Yiftah El in southern Galilee, coming from-as it was later established-approx. $7000 \mathrm{BC}[2,3]$.

However, the rapid development in the application of this construction material in industry occurred in modern times despite the fact that the history of concrete is over 9000 years old. Concrete began to be the leading material in human civilization exactly on 21 October 1824 in Leeds (England), when the production of the artificial binder-the ordinary Portland cement (OPC), which is the main binder in concrete-was patented by an English bricklayer and explorer Joseph Aspidin. It is worth mentioning that concrete-which is made with OPC - soon after its patenting, became the most widely used man-made material. The increase in the concrete's world production has been so rapid and, at the same time, significant that currently more than $1 \mathrm{~m}^{3}$ (by volume) and $2.5 \mathrm{t}$ (by weight) of concrete per earth inhabitant is produced every year. Therefore, concrete, with current production of around 10 billion tons per year, is the main civilization material with high durability, e.g., [4]. The fact that OPC production increased from several dozen tons in 1824 to 1.7, 3.3, and 4.1 billion tons in 2000, 2010, and 2019 respectively, is also significant [5]. 
Based on the Mineral Commodity Summaries, elaborated each year by the U.S. Department of the Interior U.S. Geological Survey, Figure 1 shows exactly how the amount of cement produced has changed over the first 20 years of the 21st century. The figure also presents information regarding the global production of clinker, i.e., the basic material from which OPC is made [5].

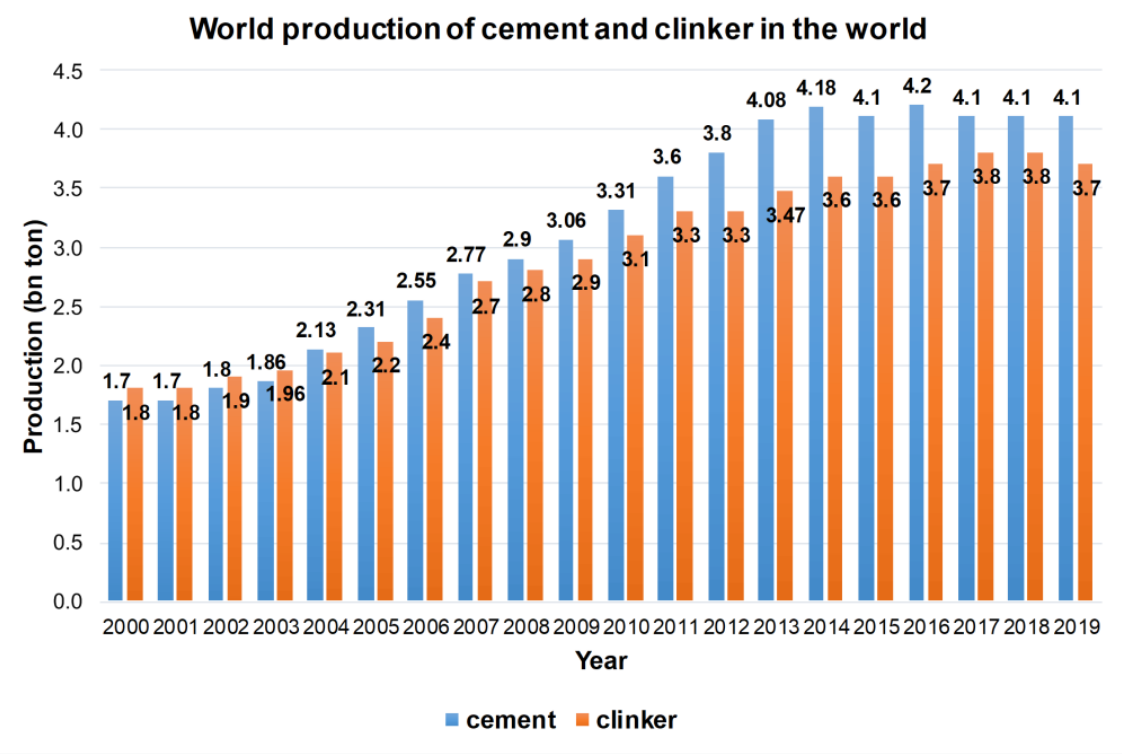

Figure 1. World cement and clinker production at the beginning of the 21st century [5].

From the figure, it can be concluded that there has been stabilization in the quantity of both materials produced over the last period after the dynamic and significant increase in the production of clinker and cement binder during the first 15 years of the 21st century. It can be noticed that the global cement production is equal to approx. 4.1 billion tonnes, while clinker is produced in an amount of 3.6 to 3.8 billion tonnes per year (Figure 1). Moreover, Figure 2 reveals the latest data on OPC and clinker production, including countries with the largest global share in this branch of industry.

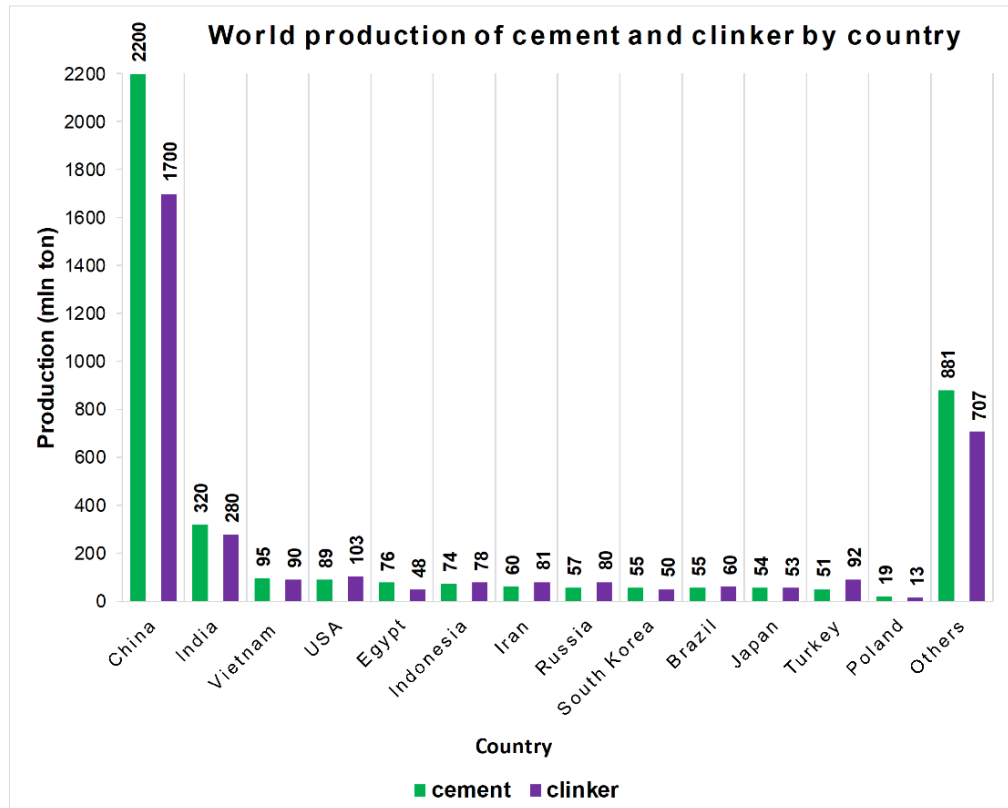

Figure 2. World production of cement and clinker by country in 2019 [5]. 
However, geographical maps showing the graphical intensity of cement production in individual countries and in the country with the largest annual production of this binder, i.e., in China (Figure 2) are shown in [6,7], respectively.

Based on the above data (Figure 2), it can be noticed that, for many years, two Asian countries, i.e., China and India, have been the leader in OPC and clinker production [7]. In addition, an over 50\% share of China in the above summaries can also be noticed. In the case of these countries (as well as several other, e.g., Vietnam, Egypt, and Japan), significantly lower level of clinker produced can be seen in relation to the amount of cement produced. This proves that these countries are implementing the principles of sustainable development (production of sustainable OPC), of which one of the goals is to replace the clinker components in OPC composition with other materials, the so-called cement binder substitutes (see Section 2).

Generally, the goal of such actions, which have been implemented for many years, is: to reduce the environmental pollution from cement production and the damage to natural resources from aggregate mining in the concrete industry [8], and to limit the use of natural raw materials needed for clinker burning (this process requires approximately 1.7 tons of raw materials, mainly limestone, per ton of clinker produced [9]; 6.97 bn tons per year), as a result of which it would be possible to reduce the amount of energy that is needed to produce cement and reduce the greenhouse gases (GHG) generated in these processes; mainly $\mathrm{CO}_{2}$. Therefore, the assumption of the production of low-emission cements would be possible with a reduction of the clinker/cement ratio to 0.7 , which is supposed to happen in 2050. Currently, although the indicator gradually decreases, it is still at a very high level. In 2000, it was equal to 1.06, while in 2010-0.94 (Figure 2). The current clinker/cement ratio is 0.9 (Figure 3), which is definitely too high when comparing with the plans for the implementation of green technologies in the cement industry, e.g., [10-15].

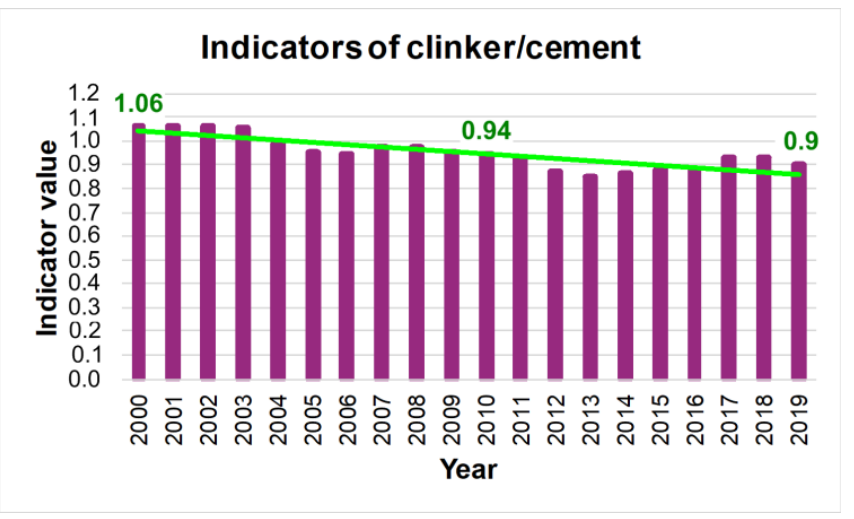

Figure 3. Changes in the clinker/cement index at the beginning of the 21st century.

Unfortunately, some of the countries with the largest share in the production of OPC do not comply with the concept of lowering the clinker/cement ratio. Countries, such as: USA, Russia, Iran, and Turkey produce much more clinker in relation to the amount of cement produced (Figure 2). This indicates that these countries do not comply with the principles of sustainable development in the cement production process as well as the low energy efficiency of the cement plants in these countries.

Moreover, the OPC manufacturing process is energy intensive and the depletion of natural resources, such as limestone [16,17] (see Section 2). Therefore, the only proper course of action for the cement-concrete industry is a further research on the improvement of its parameters, optimization, and development of its applications, as well as the analysis of the best available techniques and production technologies in terms of environmentally friendly impact. Thanks to these activities, it could be possible in the near future to include cement production process in the low carbon economy. This would be based on reducing the energy consumption in the clinker burning process and binder production. Such actions would also significantly reduce the consumption of natural resources, e.g., [18-22]. 
Absolutely, in the cement industry, the utilization of a sustainable binder that has a lower energy consumption and carbon dioxide $\left(\mathrm{CO}_{2}\right)$ emission than OPC is becoming increasingly important [23].

Therefore, the continuous development in the field of new technologies of the production of concrete mixes, focusing on both the economic and environmental aspects, leads to the search for increasingly innovative and useful solutions. One of these solutions can be application of fabric reinforced cementitious mortar composites (FRCM). This proposal is a new and valid solution in the field of strengthening of existing masonry and reinforced concrete structure, e.g., [24,25].

Therefore, in the following article, the most commonly used methods are discussed in order to reduce the impact of cement and concrete production on the environment. On the other hand, one of the most innovative concepts aimed at conscious and effective improvement of concrete composite parameters, i.e., the modification of concrete using nanotechnology, was broadly presented, e.g., [26,27]. The presented technological solution was also referred to clear benefits associated with reducing energy consumption as a result of its use.

The article also proposes a proprietary solution for the material modification of concrete with the combined use of three nanoadditives, i.e.: siliceous fly ash (FA), microsilica (SF), and nanosilica (nS) [28-35]. The aim of this concept would be a synergistic effect for improving the properties of modified composites as a result of the interaction of three active pozzolanic cement binder substitutes. The proposal of limiting cement consumption as a result of replacing it with useful industrial waste was supported by the results of our own tests of concrete for the production of which a binder modified with three nanoadditives was used. Such actions allowed for:

- a clear improvement in the basic mechanical parameters of concrete composites, i.e., compressive and tensile strength and

- the reduction of natural resources and energy consumption required in the OPC production process.

\section{Energy Consumption in Cement Production Process and Concepts of Its Reduction}

The production of Portland clinker and subsequent production of cement is a multi-stage process and it requires considerable amounts of energy. Energy is necessary to carry out individual technological operations, from the extraction of raw materials that are needed to burn clinker to the transport of the finished binder to the concrete plant [36-38]. According to [39], Figure 4 provides a process flow diagram of the general cement production process and the associated inputs, during various steps of the production process.

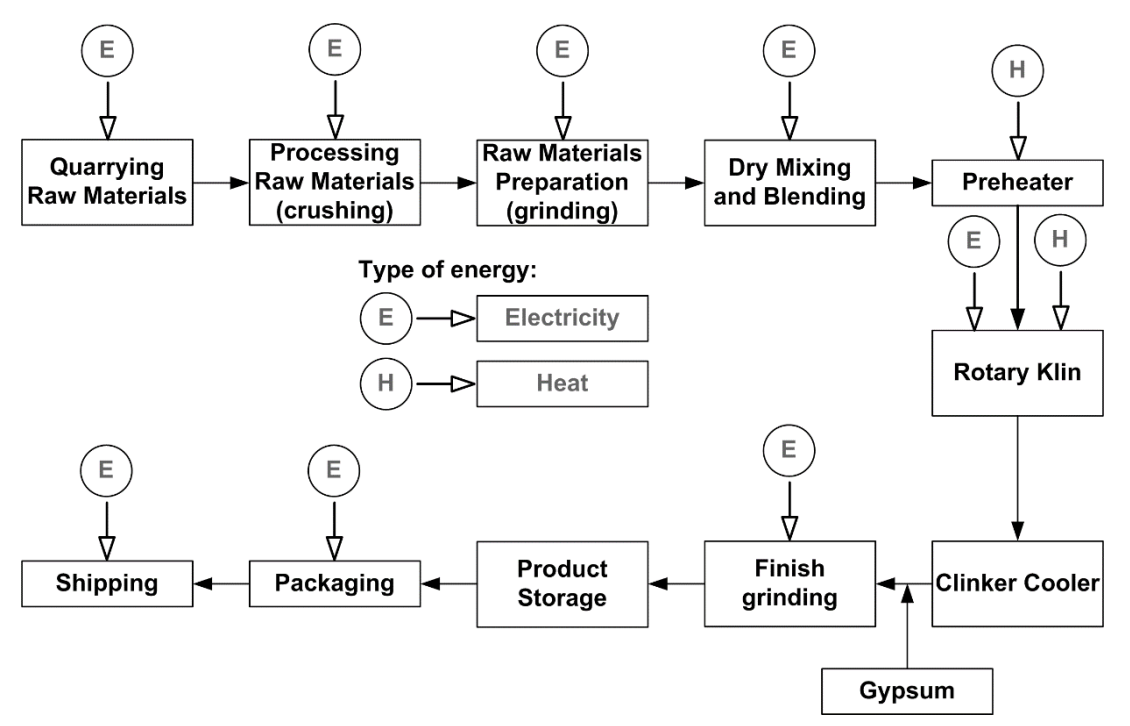

Figure 4. Process flow diagram for the cement manufacturing process, showing electricity and heat consumption or inputs [39]. 
In general, the following types of energy consumption needed at different stages of OPC production can be distinguished [38]:

- electricity consumption for production of clinker,

- electricity consumption for production of cement,

- specific consumption of electricity for clinker,

- specific consumption of electricity for cement,

- electricity consumption for other activities in the plant, and

- fuel consumption.

In addition, it should be noted that thermal and electrical energy are both needed in the entire cement production process (Figure 4) [39]. Its necessary amount required to produce cement (especially in the case of electricity) also depends on the technology used to prepare raw materials for clinker burning. The wet method is definitely more energy-consuming. This is why it is successively replaced by the more economical dry method (Table 1$)$.

Table 1. Total thermal and electrical energy consumption in dry and wet process $[39,40]$.

\begin{tabular}{ccc}
\hline \multirow{2}{*}{ Type of Energy } & \multicolumn{2}{c}{ Type of Method } \\
\cline { 2 - 3 } & Dry Process & Wet Process \\
\hline Thermal energy consumption (GJ/ton clinker) & 4.60 & $5.86-6.28$ \\
Total electricity required (kWh/ton clinker) & 130 & 149 \\
\hline
\end{tabular}

Based on the papers $[39,40]$, Table 1 presents the total thermal energy consumption and total electricity required in clinker manufacturing process. The table includes the division into the amount of necessary energy required for both the dry and wet method. However, the detailed consumption of thermal and electrical energy at individual stages of clinker burning and cement production are given in $[39,40]$. Furthermore, Table 2 summarizes the average specific thermal and electrical energy consumption for few selected countries [39,40]. During the analysis, the countries with the lowest, highest, and average energy consumption were taken into account. Other detailed data on energy consumption during cement production in selected countries, such as: Poland, India, or Croatia, are given in the papers [41-43], respectively.

Table 2. Comparison of electrical and thermal specific energy consumption (SEC) for few selected countries around the world $[39,40]$.

\begin{tabular}{ccc}
\hline \multirow{2}{*}{ Country } & \multicolumn{2}{c}{ Type of SEC } \\
\cline { 2 - 3 } & Electrical SEC (kWh/ton) & Thermal SEC (GJ/ton) \\
\hline India & 88 & 3.00 \\
China & 118 & 4.00 \\
United States & 141 & 4.60 \\
World best & 65 & 2.72 \\
\hline
\end{tabular}

Based on data that are presented in Table 2, it can be stated that the annual consumption of thermal and electrical energy in the cement production process is in the range of 3.0-4.6 GJ/ton and $88-141 \mathrm{kWh} /$ ton $[39,40]$. However, it was estimated that a typical, well-equipped cement plant consumes approximately $4 \mathrm{GJ}$ energy to produce one ton of cement, according to other literature data (having regard to the share of all the above-mentioned types of energy that are necessary in the cement production process) (Figure 3) [44]. This value corresponds to the consumption of thermal energy in OPC production process in China, which is a country that produces more than half of the annual global resources of this binder (Figure 2). Therefore, thermal and electrical energy consumption indicators in cement production for China were taken into account in further considerations. The reference to 
the energy consumed by this country is also justified as the values of the annual consumption of both types of energy in OPC production process for China are intermediate between the upper and lower limits for both thermal and electrical energy (Table 2).

Therefore, in conjunction with data on the annual cement production (Figure 1), it can be concluded that, currently, in global terms, the production of this binder consumes approx. per annum:

- 16 EJ of thermal energy and

- 484 TWh of electrical energy.

Therefore, the reduction of energy consumption in the cement binder production process has been one of the priority issues of engineering and environmental protection for a long time. Various standard ways for saving energy in cement production are given in [45]. For this purpose, research is conducted as well as new material and technological solutions are proposed and partly implemented. Their primary goal is to reduce as much energy consumption as possible, which is necessary in OPC production at almost all stages (Figure 4). Therefore, there is an increasing number of new concepts of sustainable cement production, i.e., a binder generating less negative impact on the environment and the economy, e.g., [46-55]. Therefore, research on innovative solutions in this field covers many areas. They mainly concern the following:

- increase of the energy efficiency in OPC production process due to the implementation of modern technologies for preparing raw materials for clinker burning while using the dry method and the resignation from the more energy-consuming and outdated wet method, e.g., [56],

- improvement of energy efficiency in the context of a significant reduction of thermal energy consumption in OPC production process, e.g., [18-22],

- capturing and storage of $\mathrm{CO}_{2}$, e.g., [49,56,57],

- increase in the share of alternative fuels to replace coal and coke in the cement kiln firing process, e.g., $[9,40,58-62]$, and

- replacing clinker in cement by other mineral or non-mineral components (e.g., fly ash, furnace slag, silica fume, and others), referred to as supplementary cementitious materials (SCMs), e.g., [63-74].

It is particularly important to implement the last two concepts in the cement binder production process from the point of view of environmental protection. Both of them relate to the possibility of using previously used materials. In most cases, these are the problematic and even dangerous residues from the production processes from other sectors of the economy. Their brief characteristics are presented below.

Alternative fuels are another source of energy used by cement producers around the world. They can replace the basic sources of energy used by cement kilns to produce the high temperatures that are necessary for the formation of clinker, such as: coal, fuel oil, petroleum coke, and natural gas [61]. These fuels are usually derived from the mixtures of industrial, municipal and hazardous wastes [53]. Alternative fuels used in cement industries can be solid or liquid. They are required to have an appropriate chemical content, depending on the type of components and their organic contents [61].

There are five main groups of solid alternative fuels and they are listed below:

(1) Agricultural biomass residues.

(2) Non-agricultural biomass residues.

(3) Petroleum based wastes.

(4) Miscellaneous wastes.

(5) Chemical and hazardous wastes.

In addition, specific types and corresponding kinds of alternative fuels can be distinguished (they are given in details in [10,59-63]), i.e.: 
(a) liquid waste fuels,

(b) solid waste fuels, and

(c) gaseous waste.

Limiting the amount of clinker in the binder composition through various non-clinker materials, such as SCMs, is another way that can significantly reduce energy consumption in the cement production process. This is confirmed by, among others, analyzes presented in [66].

Until recently, this group only included standard and verified binder substitutes mainly in the form of small and reactive mineral additives (e.g., fly ash, silica fume, granulated furnace slag). As these materials, being a problematic industrial waste, positively affected the parameters of concrete composites and were effectively utilized (in concrete technology), the concepts of cement binder substitution have been evaluated and developed dynamically. Therefore, attempts were made and intensive research was carried out on the possibility of using more and more new materials in the composition of the concrete mix, which are a problematic waste in various industries. As a result of this, attention was paid to many other areas of human activity producing in large amounts of waste, which at the same time could be the valuable modifiers of the composite structure. Therefore, various agricultural waste, fish farming waste, as well as ceramic and glass waste are used in concrete. Such actions, in the context of environmental protection, are justified, because, as demonstrated in numerous studies, substituting OPC with SMCs in concrete mix causes an almost perfectly linear reduction of the energy consumption necessary in the cement binder production process, e.g., [75].

In general, there are six main groups of SCMs and they are listed below:

(1) Industrial wastes.

(2) Nano industrial wastes.

(3) Agriculture farming waste.

(4) Aquaculture farming wastes.

(5) Natural minerals.

(6) Dust and powders.

Most of the concrete structure modifiers that are presented in the above groups are widely known and used. However, the progress in the modification of concrete composition has been inspired by the achievements of learning about new, unusual materials for many years.

The current development in the engineering of building materials is unquestionably evolving towards learning and improving the structure of concrete composites at the micro- and nanoscale levels. This situation is certainly influenced by an increasing amount of financial expenses on this branch of science (calculated in million Euros per year) and, thus, by more and more advanced research as well as more and more spectacular results. It can be stated that, in recent years, there has been a revolution in the nanotechnology that has had a huge impact on various fields of science, such as: chemistry, engineering, and biology [76]. Significant traces of nanotechnology can be found in the field of technology for a long time in: information technology, electrical engineering, electronics, materials science, and robotics. It is also impossible not to notice them in the area of concrete and concrete structures [77]. It is anticipated that the nanomodification will be the dominant path in the development of modern building materials through the optimal selection of nanoparticles that effectively modify their structure.

An important area, in which the quickly developing nanotechnology follows the growing requirements of the materials producers, is the construction industry. Although a lot of products based on the nanotechnology are already available on the construction market, the most modern applications are presently developed, which are dedicated to the building materials. Nanotechnology brings the outstanding, improved properties to this sector, such as mechanical strength, biological resistance, self-cleaning ability, energy saving, and thermal insulation, leading to the revolution in the sustainable construction: safe and relatively cheap buildings, railways, airport pavements, and roads [78]. 
In the construction industry, one of the most important areas, in which the use of nanotechnology is quite transparent, is associated with the production of concrete. Nanotechnology has great potential in the contribution to understanding the behaviour of this material, to improve its mechanical properties, to reduce production costs, and to implement concepts and ecological materials on a larger scale, e.g., [79].

Nanoengineering allows for grasping problems from the nano- to macro-scale and justifies the technical properties of materials, referring to their structure. The group of concrete nanomodifiers includes both nanoadditives and nanoadmixtures, e.g., [80,81].

Therefore, bearing the numerous advantages associated with the use of nanoadditives in concrete technology in mind, the following article presents the results of testing concrete of which cement binder has undergone multi-material modification. For this purpose, two traditional cement binder substitutes were used, i.e., siliceous fly ash (FA) and non-condensed silica fume (SF), as well as modern nanoadditive in the form of nanosilica (nS).

On the other hand, low-calcium fly ash, high-calcium fly ash, and granulated blast furnace slag are the most widely known, standardized, and used SCMs in cement and concrete composition $[80,81]$. However, among the above mentioned alternative materials, fly ash (FA), a by-product of thermal generation in coal power stations, appears to be one of the most commonly used materials in industry, e.g., [82-84]. It should be added that the most important characteristics that determine the benefits of substituting OPC with FA are primarily the high pozzolanic activity of these materials and their fine graining.

Therefore, microscopic analysis of FA particles will be a part of the studies (see Section 4.2). Moreover, due to the fine particle size and high reactivity of the FA, it was assumed that this material would be the main modifier of the structure of the analyzed composites.

At this point, it should be emphasized that FA is an abundant commodity in many countries using steam coal for power production. There are hundreds millions tons of industrial waste produced annually across the World, as FA is a by-product obtained in the process of hard coal combustion. Up to date -800 millions tones of the FA is generated each year in the World [85] and, in the future, one should expect to increase this quantity to 2100 million tones in 2031-32 [86]. It is also known, from numerous literature reports, that this waste material is used to a greater or lesser extent in many countries around the world, e.g., [85,87-89]. According to [87], in some countries (e.g., Israel), all of the FA is utilized whereas in some countries only low percentage is used (e.g., USA). Blisset and Rowson indicate that FA utilization are $39 \%$ in the USA and $47 \%$ in Europe, whereas the global average is estimated to be close to $25 \%$ [88]. It means that this is approximately 200 millions tones per annum [83]. Other literature data indicate that FA utilization rates of $50 \%$ for the USA, over $90 \%$ for the Eurpean Union, and respectively $67 \%$ for China and $60 \%$ for India [89].

Therefore, the use of FA in the concrete industry and other industries is significant. On the other hand, their quality determines the possibility of their use in the composition of the concrete mix, because the provenance of the FA can affect the mechanical properties of concrete elements. However, as demonstrated [90], in practice mainly used locally available FA.

Furthermore, no reports were found that this material was forbidden for use as a substitute for cement binder. However, it was shown that replacement of cement with FA is an important task from the ecological point of view and is clearly environmentally friendly activity, through such actions as [91-94]:

- reduction of FA landfills,

- reduction of extraction of natural resources,

- reduction of energy consumption needed to produce clinker, and

- reduction of $\mathrm{CO}_{2}$ emission produced during the production of clinker and cement.

Similar advantages are also obtained while using other SCMs, which have been characterized above. 
It should also be noted that, based on previous studies, the effect of the modification of concrete composites FA in the amount of 20 and $30 \%$ of cement weight was recognized quite well, e.g., $[32,63-65,95]$. On the other hand, it is also known that the most beneficial effects are brought by the modification of the concrete structure SF in the amount of $10 \%$, while nS - 5\%, e.g., [96-98].

The parameters of concrete composites, for which three analysed mineral additives were separately used, have already been well recognized, e.g., [99]. However, in the presented experiments, it is planned to examine the interaction of pozzolanic additives and assess their synergies in relation to improving the mechanical parameters of cement-based concrete. Considering the occurrence of the main binder, i.e., OPC, it should be stated that the analysed concretes will contain a matrix based on quaternary binders, e.g., [100-113].

It should be noted that concretes that are based on the structure of four different binders have already been the subject of several publications. Some of them, e.g., [100] have been published even in this year, which indicates that this topic is not fully recognized. The properties of such materials were most often analyzed in terms of assessing their mechanical parameters, e.g., [101-105], checking the intensification of hydration processes as a result of the proposed material modification, e.g., [107] and the effect of such solutions on improving the corrosion resistance of composites, e.g., [104]. These experiments concerned ordinary $[95,96,106,109]$, self-compacting $[105,106,109]$, and high performance concretes $[109,110]$.

However, in previous studies the composition of modified binders was based, apart from OPC, only on traditional SCMs, such as: FA, SF, furnace slag (FS), and metakaolin (MK), e.g., [103]. Tests have also been carried out while using powders as modifiers, i.e., limestone powder (LM) and marble powder, e.g., (MP) [102]. In the literature, there were no results of testing the properties of concretes made on quaternary binders, which would contain nanoadditives.

Therefore, the scope of undertaken research included:

- analysis of mechanical parameters of concrete composites made on quaternary binders with nanomaterials,

- microstructural examinations of the main concrete modifier, i.e., grains of fly ash, and

- assessment of the amount of thermal and electrical energy as well as raw materials that could be saved as a result of the proposed material modification.

\section{Experimental Section}

\subsection{Materials}

All of the materials (exluded nanosilica) used in the studies came from the area of Polish. Nanosilica was imported from South Korea. The following materials were used for making the mixtures:

- ordinary Portland ceement CEM I 32.5 R from Chełm cement plant, with: the compressive strength equal to $23.3 \mathrm{MPa}$ in the age of two days and $50 \mathrm{MPa}$ after 28 days of curing, specific surface area $0.33 \mathrm{~m}^{2} / \mathrm{g}$, specific gravity $3.11 \mathrm{~g} / \mathrm{cm}^{3}$, mineralogical composition in accordance to the standard EN 197-1:2011- Cement - Part 1 [114],

- class F fly ash from local power plant is a result of energetic combustion of hard coal in the Puławy thermal-electric power station, with specific surface area $0.36 \mathrm{~m}^{2} / \mathrm{g}$ and specific gravity $2.14 \mathrm{~g} / \mathrm{cm}^{3}$,

- non-condensed silica fume from Łaziska Ironworks, with specific surface area $1.40 \mathrm{~m}^{2} / \mathrm{g}$ and specific gravity $2.21 \mathrm{~g} / \mathrm{cm}^{3}$,

- nanosilica Konasil K-200 from OCI Company Ltd., with specific surface area $200 \mathrm{~m}^{2} / \mathrm{g}$ and specific gravity $1.10 \mathrm{~g} / \mathrm{cm}^{3}$,

- natural gravel aggregates of maximum grain size up to $8 \mathrm{~mm}$, from Las Suwalski deposit, with specific density $2.65 \mathrm{~g} / \mathrm{cm}^{3}$ and compressive strength $34 \mathrm{MPa}$,

- a pit sand from Markuszów deposit with: siliceous nature, a maximum diameter of $2 \mathrm{~mm}$, specific density $2.60 \mathrm{~g} / \mathrm{cm}^{3}$ and compressive strength $33 \mathrm{MPa}$, 
- superplasticizer STACHEMENT 2750 based on polycarboxylates; $1.8 \%$ of -binding material weight, with a very high liquefaction effect-which is retained for a longer period than with the common used superplasticizers,

- laboratory pipeline water free from contamination,

- In elaboration of recipes of concrete mixtures having the additives one took an assumptions that:

- the total amount of binding material in the concretes will be constant,

- the constant amount of the binder substitute at $10 \%$ and $5 \%$ was for SF and nS, respectively,

- a variable parameter was the addition of FA, which replaced the OPC in the amount of: $0 \%, 5 \%$ and $15 \%$, and

- the same water-binder ratio at level 0.4 in all mixtures.

Based on the above, during the design of the experiments, the following compositions of concrete mixes with various amounts of additions were planned:

- REF-without any additives,

- $\quad$ FA-00+SF-10+nS-5;

- $\quad$ FA-5+SF-10+nS-5; and,

- $\quad$ FA-15+SF-10+nS-5.

The specimens for strengths tests were made of concrete mixtures in which solid contents of: binder, sand, gravel, water, and superplasticizer-in the following quantities: 352, 676, 1205, 141, and $6 \mathrm{~kg} / \mathrm{m}^{3}$, respectively were used. Figure 5 shows the appearance of all materials used in the studies.

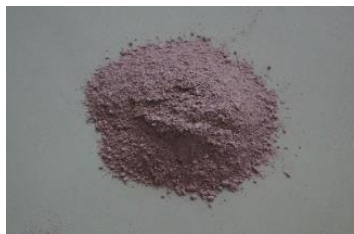

(a)

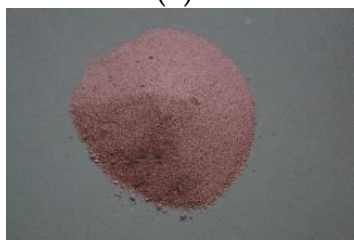

(e)

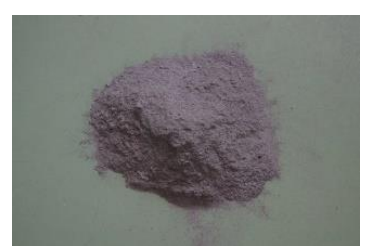

(b)

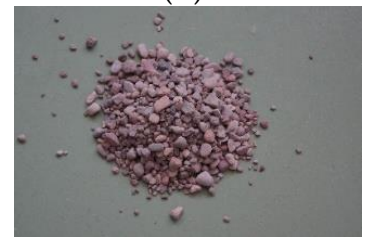

(f)

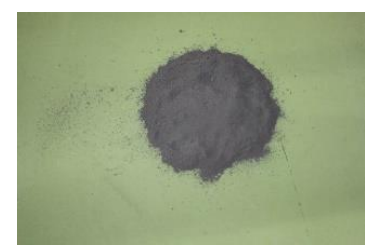

(c)

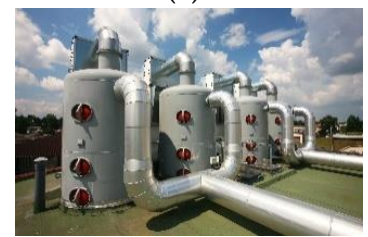

(g)

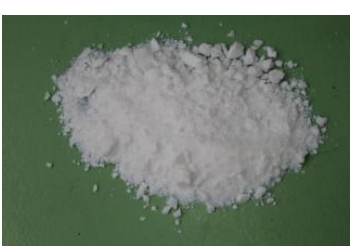

(d)

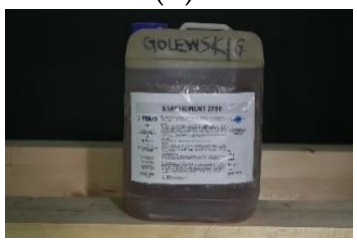

(h)

Figure 5. Appearance of materials used in the studies: (a) cement; (b) fly ash; (c) silica fume; (d) nanosilica; (e) fine aggregate; (f) coarse aggregate; (g) water; and, (h) superplasticizer.

Gravel and sand were both dry mixed in a drum mixer for $2 \mathrm{~min}$. followed by addition of the binder materials (OPC and FA) which was further mixed for $3 \mathrm{~min}$. Subsequently, half of the mixing water was added for mixing of $2 \mathrm{~min}$. and followed by the remaining water and superplasticizer.

The superplasticizer was dosed in a very large amount, i.e., $1.8 \%$ of binding material $(0.6 \%$ above the upper recommended limit) due to the reduced workability of the concrete mix due to the addition up to three microfillers, i.e., FA, SF, and nS. This allowed for freely molding specimens.

The cast specimens were covered with a polyurethane sheet and damped cloth. After two days, all of the specimens were demoulded. Afterwards, they were kept for 14 days in a chamber with a moisture-saturated atmosphere and for another 14 days under laboratory conditions $\left(20 \pm 2{ }^{\circ} \mathrm{C}\right)$. After 28 days of curing, the compressive strength tests and splitting tensile strength tests were carried out. 


\subsection{Methods}

In the experimental part, this article focuses on analysing compressive strength $\left(f_{\mathrm{cm}}\right)$ and splitting tensile strength $\left(f_{\mathrm{ctm}}\right)$ in concrete made with quaternary binders. Analysis of strength parameters were conducted on six specimens, made for each series of concrete, after 28 days of their curing. In concretes with modified matrix, OPC was replaced by pozzolanic additives by weight.

All of the tests were carried out on cubic specimens with dimensions: $150 \times 150 \times 150 \mathrm{~mm}$. The main steps of preparing specimens for tests included the following activities:

- Lubrication the molds with an anti-adhesive agent.

- Preparation of a concrete mixture.

- Casting of cubes in plastic forms.

- Curing of the specimens after casting. This procedure lasted two days.

- Demoulding of cubes by using compressor.

- Curing of the specimens in a chamber with a moisture-saturated atmosphere. This procedure lasted two weeks.

- Removing specimens from the water.

- Final preparation of specimens for testing.

Compression and tensile strength were both tested using a compression machine (Walter + Bai ag) with a maximum load of $3000 \mathrm{kN}$. The specimens were loaded statically. The compressive strength tests and the splitting tensile strength tests were both conducted according to the standards of series EN 12390, exactly according to the standards:

- EN 12390-3:2011+AC: 2012 Testing hardened concrete-Part 3: Compressive strength of test specimens [115] and

- EN 12390-6:2009 Testing hardened concrete-Part 6: Tensile splitting strenght of test specimens [116].

In addition to testing the mechanical parameters of concretes, the microstructure of the grains of main modifier, i.e., FA, was also analysed. In own studies, microscopic observations were carried out with application of the Scanning Electron Microscope (SEM) to assess the microstructure of the FA. SEM is one of the best and most widely used techniques for the chemical and physical characterization of the FA, as noted by Vassilev and Vassileva [117].

The microstructural testing was carried out using a QUANTA FEG 250, which was equipped with an energy dispersive Spectroscopy (EDS EDAX), at magnification from 200 up to 80,000 times. The tests were performed in both the low and high vacuum by using secondary electrons (SE).

Except for assessing strength parameters in concretes modified with pozzolanic additives and microstructure of FA particles, the additional purpose of the study was to determine the environmental benefits associated with the possibility of reducing:

- raw materials for burning clinker,

- heat energy consumption, and

- electricity consumption.

as a result of limiting the use of OPC in the composition of the concrete mixture and replacing this basic binder with fine and reactive SCMs.

\section{Results and Discussions}

\subsection{Mechanical Parameters}

The average values of compressive strength and splitting tensile strength of concretes, after 28 days of their curing, (with error bars) are given in Figures 6 and 7, respectively. In addition, Table 3 
presents the percentage increases of both analysed mechanical parameters in relation to the values that were obtained for the reference concrete.

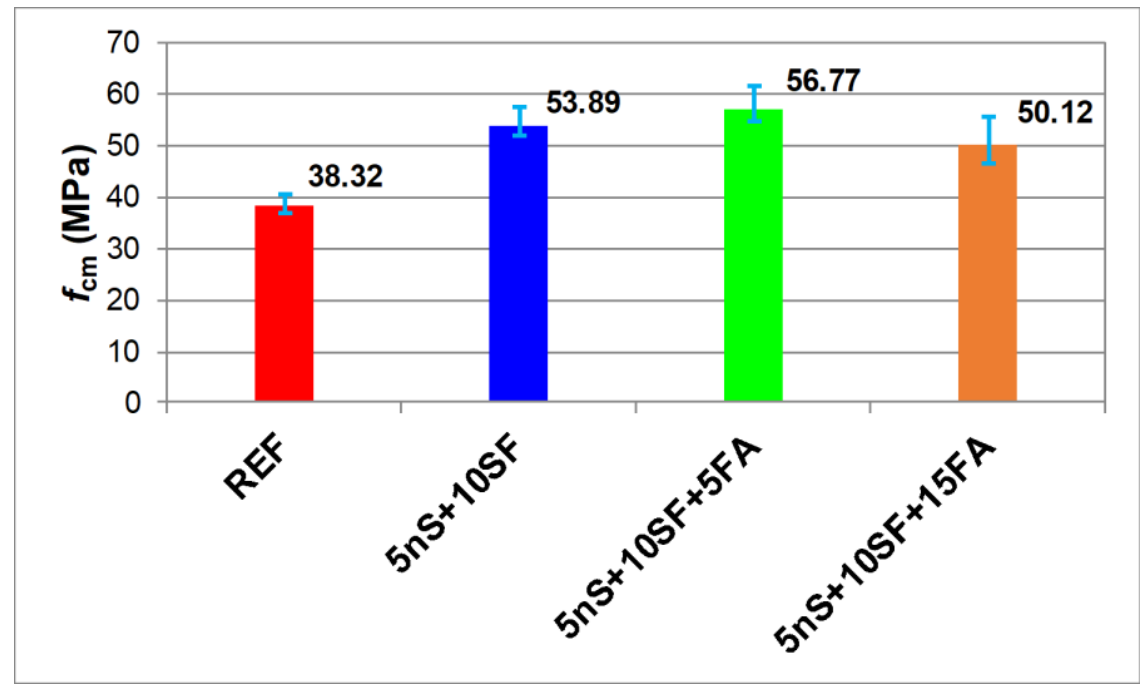

Figure 6. Results of compressive strength of concretes.

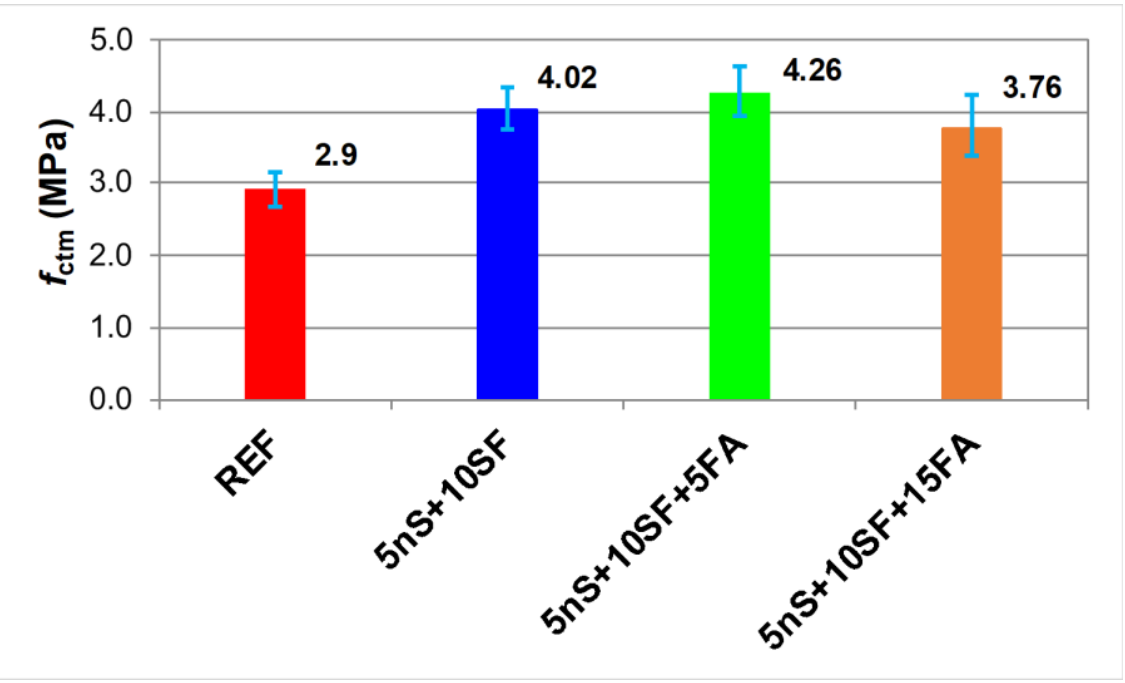

Figure 7. Results of splitting tensile strength of concretes.

Table 3. Compressive strength and splitting tensile strength of concretes.

\begin{tabular}{ccc}
\hline \multirow{2}{*}{ Mix } & \multicolumn{2}{c}{ The Values of Analysed Parameters Compared to Concrete REF (\%) } \\
\cline { 2 - 3 } & $f_{\mathrm{cm}}$ & $f_{\mathrm{ctm}}$ \\
\hline REF & 100 & 100 \\
FA-00+SF-10+Ns-5 & 140.6 & 138.6 \\
FA-5+SF-10+Ns-5 & 148.2 & 146.9 \\
FA-15+SF-10+Ns-5 & 130.8 & 129.7 \\
\hline
\end{tabular}

When analysing the results obtained for both $f_{\mathrm{cm}}$ and $f_{\mathrm{ctm}}$, it should be stated that the highest indices of strength, both compressive and tensile, had concrete with a quaternary binder, containing a smaller proportion of FA, i.e., $5 \%$. Therefore, an increase of over $40 \%$ in both strengths was observed in comparison to the reference concrete in the case of concrete of series FA-5+SF-10+Ns-5 (Table 3). The other two modified matrix composites also had higher mechanical parameters when compared to 
REF concrete. However, the $f_{\mathrm{cm}}$ and $f_{\mathrm{ctm}}$ values for these materials were about a dozen or so percent lower when compared to the results obtained for the concrete with the best parameters. Definitely the least favourable effect of modification was achieved for the 15\% FA concrete. Although this substitute was characterized by fine granulation and high reactivity (Figures 8 and 9) with a larger amount of this additive, the effect of reducing the strength of the composite, which was characteristic for FA, during the period below 90 days of curing became visible [95,118]. Moreover, it was observed that the results of compressive strength and splitting tensile strength in quaternary concretes are qualitatively convergent.

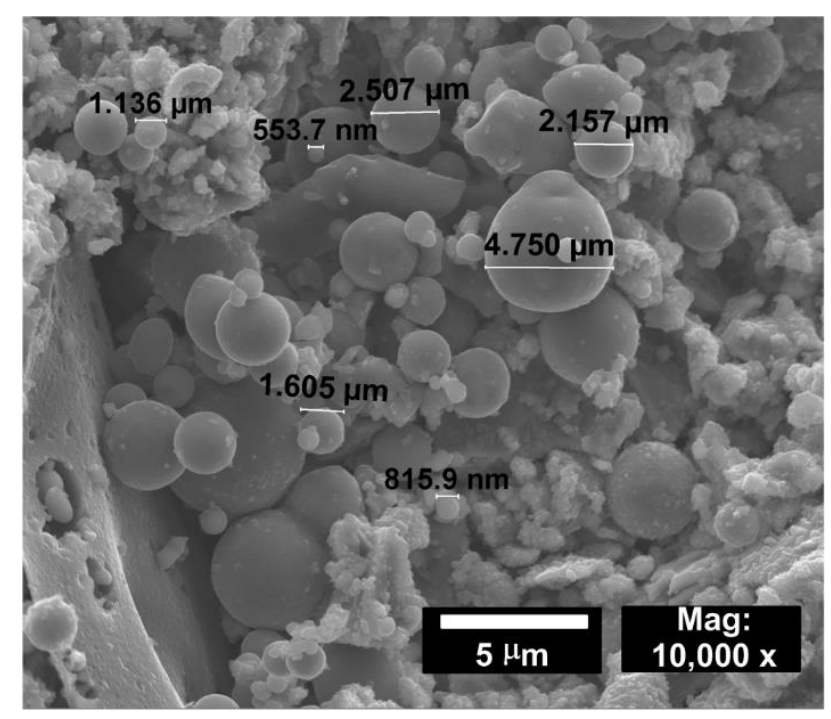

Figure 8. A view of fine fly ash particles used in the studies.

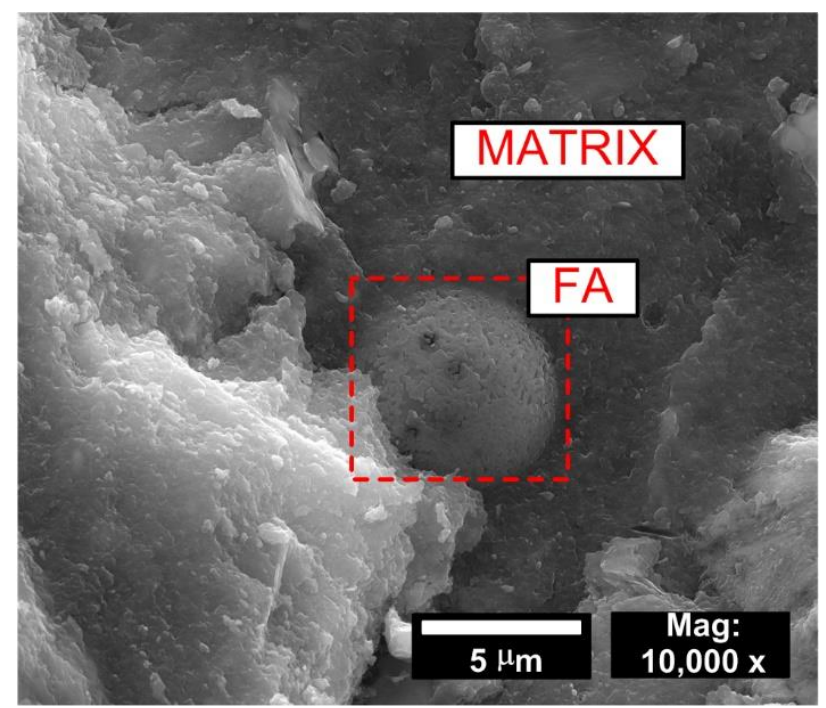

Figure 9. Fly ash grain during pozzolanic reaction.

It should also be noted that, in all series of concrete with quaternary binders, the results $f_{\mathrm{cm}}$ and $f_{\text {ctm }}$ clearly exceeded the values of strength parameters that were obtained for unmodified concrete. In the case of compressive strength, an advantage ranging from $30 \%$ to $48 \%$ was obtained, while, in the case of tensile strength-from $30 \%$ to almost $47 \%$. Therefore, it should be recognized that all of the proposed compositions of concrete mixtures were characterized by very favourable mechanical parameters. In the case of concrete of FA-5+SF-10+Ns-5 series, the obtained strengths were close to the strengths obtained for the high-performance concretes. 


\subsection{Microstructural Analysis}

Figure 8 shows a view of FA grains, in which particles with a diameter of a few to several $\mu \mathrm{m}$ prevail. This is one of the forms of FA grains occurring in larger quantities. Figure 8 shows the FA agglomerate. Agglomerates were composed of different fractions of FA, most often in sizes from 1.0 to several dozen $\mu \mathrm{m}$. An interesting forms of FA of this type were also shown in [119].

Figure 9 shows the responsive FA grain that was observed in the cement matrix structure after 28 days of curing. The grain surface exposes a highly advanced pozzolanic reaction process and it is well embedded in the matrix structure, i.e., it has almost negligible cracks in the area of contact with the paste [120-122]. Highly responsive FA grains only after four weeks from the preparation of batches indicate that these are materials with high activity in contact with the cement matrix. Such processes are usually postponed in the case of FA modified cement paste. They become visible only after three months and sometimes even after half a year [95].

\subsection{Energy Savings}

In addition to the obvious benefits of the proposed material modification in terms of a clear improvement in the mechanical parameters of concretes, the substitution of cement binder in the composition of a concrete mix also brings definite environmental benefits. Table 4 presents the values of the annual reduction in the consumption of natural resources that are necessary in the clinker burning process and the limitations in the consumption of heat and electrical energy needed for the production of cement binder when replacing OPC with individual compositions of SCMs.

Table 4. Reduction of the annual consumption of products when replacing the OPC with three additives.

\begin{tabular}{cccccc}
\hline \multirow{2}{*}{ Analysed Product } & \multicolumn{4}{c}{ Reduction for Consumption of Product for Different Series of Concrete } & \multirow{2}{*}{ Unit } \\
\cline { 2 - 5 } & REF & FA-00+SF-10+Ns-5 & FA-5+SF-10+Ns-5 & FA-15+SF-10+Ns-5 & \\
\hline Cement & 0 & $615,000,000$ & $820,000,000$ & $1,230,000,000$ & (ton) \\
Raw materials for burning clinker & 0 & $104,550,000$ & $1,394,000,000$ & $2,091,000,000$ & (ton) \\
Electricity & 0 & 72.6 & 96.8 & 145.2 & (TWh) \\
Heat energy & 0 & 2.4 & 3.2 & 4.8 & (EJ) \\
\hline
\end{tabular}

The analysis that is presented in Table 4 were made while taking the savings that could be obtained by replacing cement with a suitable composition of additives on an annual assumption into account:

- cement production in the amount of 4.1 bn tons (Figure 1),

- consumption of natural resources in an amount of 6.97 bn tons [9],

- electricity consumption in the cement production process that occurs in China-484 TWh (Table 2), and

- heat energy consumption in the cement production process that occurs in China-16 EJ (Table 2).

As a result of using the proposed solutions, it is possible to limit the consumption of particular products:

- raw materials required for clinker burning by one- to two-billion tonnes,

- heat energy in the production of cement by 2.4 to $4.8 \mathrm{EJ}$, and,

- electricity in the production of cement by 73 to $145 \mathrm{TWh}$.

In addition, it is concluded that the greatest environmental benefits, when using concretes based on quaternary binders, are obtained when using the concrete of series FA-15+SF-10+Ns- 5 based on data in Table 4 (30\% OPC substitution). The smallest reduction in the consumption of particular products can be obtained when only SF and Ns are added to concrete (OPC substitution at 15\%).

\section{Conclusions}

This study investigates the behavior of quaternary concrete after incorporating: FA, SF, and nS. The experimental results revealed that the addition of SCMs, such as: FA, SF, and nS in OPC very 
positively affects the mechanical properties of concrete. The article also highlights the environmental aspect of the proposed solutions.

Based on the test results, the following conclusions can be drawn:

(1) Concretes containing fly ash and nanoadditives in the cement composition have very favourable strength parameters- $30 \%$ to over $40 \%$ in relation to the values obtained for concrete without additives.

(2) The quaternary concrete containing: $80 \%$ OPC, $5 \%$ FA, $10 \%$ SF, and $5 \%$ nS have shown the best results of compressive strength and splitting tensile strength.

(3) The worst mechanical parameters were characterized by concrete containing more content of FA additive in the concrete mix, i.e., $15 \%$ (70\% OPC + 15\% FA + 10\% SF + 5\% nS).

(4) The results of compressive strength and splitting tensile strength are convergent qualitatively.

(5) Replacing of cement in the composition of a concrete mix, with fly ash and nanoadditives, is advantageous from an ecological point of view. It primarily allows for reduction of electricity and heat energy in the processes of cement production.

(6) Quaternary concrete containing fly ash and nanoadditives could be a good substitute of ordinary concretes. This material can promote the utilization of waste materials, such as fly ash and silica fume in construction.

Funding: The research leading to these results has received funding from the MINIATURA 2 Grant, No. 2018/02/X/ST8/02726: funded by National Science Center of Poland.

Conflicts of Interest: The author declares no conflict of interest.

\section{References}

1. Malinowski, R.; Garfinkel, Y. Prehistory of concrete. Concr. Int. 1990, 13, 62-68.

2. Bensted, J.; Coleman, N. Cement and concrete-7000 BC to 1900 AD. Cem. Wapno Beton 2003, 3, 134-142.

3. Toma, I.O.; Petrescu, T.C.; Toma, A.M.; Mihai, P.; Petcu, O.A. Evolution of concrete from a traditional material to a next generation sustainable solution. CPI Concr. Plant Int. 2020, 2, 46-53.

4. Aitcin, P.-C. Cements of yesterday and today: Concrete of tomorrow. Cem. Concr. Res. 2000, 30, 1349-1359. [CrossRef]

5. USGS. Mineral Commodity Summaries, 2001, 2011, 2020; U.S. Geological Survey: Reston, VA, USA. Available online: https://www.usgs.gov/centers/nmic/mineral-commodity-summaries (accessed on 18 February 2020).

6. Farfan, J.; Fasihi, M.; Breyer, C. Trends in the global cement industry and opportunities for long-term sustainable CCU potential for Power-to-X. J. Clean. Prod. 2019, 217, 821-835. [CrossRef]

7. Gregg, J.S.; Andres, R.J.; Marland, G. China: Emissions pattern of the world leader in $\mathrm{CO}_{2}$ emissions from fossil fuel consumption and cement production. Geoph. Res. Lett. 2008, 35, L08806. [CrossRef]

8. Zhang, H.; Liu, J.; Wu, B.; Zhang, Z. Axial compressive behaviour of geopolymer recycled lump concrete. Materials 2020, 13, 533. [CrossRef]

9. Rahman, A.; Rasul, M.G.; Khan, M.M.K.; Sharma, S. Impact of alternative fuels on the cement manufacturing plant performance: An overview. Proc. Eng. 2013, 56, 393-400. [CrossRef]

10. Zou, F.; Shen, K.; Hu, C.; Wang, F.; Yang, L.; Hu, S. Effect of sodium sulfate and C-S-H seeds on the reaction of fly ash with different amorphous alumina contents. ACS Sustain. Chem. Eng. 2020, 8, 1659-1670. [CrossRef]

11. Benehelal, E.; Zahedi, G.; Hashim, H. A novel design for green and economical cement manufacturing. J. Clean. Prod. 2012, 22, 60-66. [CrossRef]

12. Barnat-Hunek, D.; Grzegorczyk-Frańczak, M.; Szymańska-Chargot, M.; Łagód, G. Effect of eco-friendly cellulose nanocrystals on physical properties of cement mortars. Polymers 2019, 11, 2088. [CrossRef] [PubMed]

13. Thenepalili, T.; Ngoc, N.T.M.; Tuấn, L.; Son, T.H.; Hieu, H.H.; Thuy, D.T.N.; Thao, N.T.T.; Tam, D.T.T.; Huyen, N.; Van, T.T.; et al. Technological solutions for recycling ash slag from the Cao Ngan Coal Power Plant in Vietnam. Energies 2018, 11, 2018. [CrossRef] 
14. Haw, T.T.; Hart, F.; Rashidi, A.; Pasbakhsh, P. Sustainable cementitious composites reinforced with metakaolin and halloysite nanotubes for construction and building applications. Appl. Clay Sci. 2020, 188, 105533. [CrossRef]

15. Vishwakarma, V.; Ramachadran, D. Green concrete mix using solid waste and nanoparticles as alternatives-A review. Constr. Build. Mater. 2018, 162, 96-103. [CrossRef]

16. Golewski, G.L.; Sadowski, T. The fracture toughness the $K_{I I I c}$ of concretes with fly ash (FA) additive. Constr. Build. Mater. 2017, 143, 444-454. [CrossRef]

17. Ikponmwosa, E.E.; Ehikhuenmen, S.O.; Irene, K.K. Comparative study and empirical modelling of pulverized coconut shell, periwinkle shell and palm kernel shell as a pozzolans in concrete. Acta Polytech. 2019, 59, 560-572. [CrossRef]

18. Cormos, A.-M.; Dragan, S.; Petrescu, L.; Sandu, V.; Cormos, C.-C. Techno-economic and environmental evaluations of decarbonized fossil-intensive industrial processes by reactive absorption \& adsorption $\mathrm{CO}_{2}$ capture systems. Energies 2020, 13, 1268.

19. Sanjuan, M.A.; Estevez, E.; Argiz, C. Carbon dioxide absorption by blast-furnace slag mortars in function of the curing intensity. Energies 2019, 12, 2346. [CrossRef]

20. Voldsund, M.; Gardarsdottir, S.O.; Lena, E.D.; Pérez-Calvo, J.-F.; Jamali, A.; Berstad, D.; Fu, C.; Romano, M.; Roussanaly, S.; Anantharaman, R.; et al. Comparison of technologies for $\mathrm{CO}_{2}$ capture from cement production-Part 1: Technical evaluation. Energies 2019, 12, 559. [CrossRef]

21. Gardarsdottir, S.O.; Lena, E.D.; Romano, M.; Roussanaly, S.; Voldsund, M.; Pérez-Calvo, J.-F.; Berstad, D.; Fu, C.; Anantharaman, R.; Sutter, D.; et al. Comparison of technologies for $\mathrm{CO}_{2}$ capture from cement production-Part 2: Cost analysis. Energies 2019, 12, 542. [CrossRef]

22. Cao, C.; Liu, H.; Hou, Z.; Mehmood, F.; Liao, J.; Feng, W. A review of $\mathrm{CO}_{2}$ storage in view of safety and cost-effectiveness. Energies 2020, 13, 600. [CrossRef]

23. Kang, S.-H.; Kwon, Y.-H.; Moon, J. Quntitative analysis of $\mathrm{CO}_{2}$ uptake and mechanical properties of air lime-based materials. Energies 2019, 12, 2903. [CrossRef]

24. Cascardi, A.; Micelli, F.; Aiello, M.A. FRCM-confined masonry columns: Experimental investigation on the effect of the inorganic matrix properties. Constr. Build. Mater. 2018, 186, 811-825. [CrossRef]

25. Maddaloni, G.; Cascardi, A.; Balsamo, A.; Di Ludovico, M.; Micelli, F.; Aiello, M.A.; Prota, A. Confinement of full-scale masonry columns with FRCM systems. Key Eng. Mater. 2017, 747, 374-381. [CrossRef]

26. Szelag, M. Mechano-physical properties and microstructure of carbon nanotube reinforced cement paste after thermal load. Nanomaterials 2017, 7, 267. [CrossRef]

27. Szelag, M. Development of cracking patterns in modified cement matrix with microsilica. Materials 2018, 11, 1928. [CrossRef]

28. Gao, Y.; Liang, K.; Gou, Y.; Wei, S.; Shen, W.; Cheng, F. Aluminum extraction technologies from high aluminum fly ash. Rev. Chem. Eng. 2020. [CrossRef]

29. Dwivedi, A.; Jain, M.K. Fly ash-Waste management and overview: A review. Recent Res. Sci. Technol. 2014, 6, 30-35.

30. Ye, J.; Zubair, M.; Wang, S.; Cai, Y.; Zhang, P. Power production waste. Water Environ. Res. 2019, 91, 1091-1096. [CrossRef]

31. Kovacik, J.; Marsavina, L.; Linul, E. Poisson's ratio of closed-cell aluminum foams. Materials 2018, 11, 1904. [CrossRef]

32. Golewski, G.L. Estimation of the optimum content of fly ash in concrete composite based on the analysis of fracture toughness tests using various measuring systems. Constr. Build. Mater. 2019, 213, 142-155. [CrossRef]

33. Golewski, G.L.; Sadowski, T. A study of mode III fracture toughness in young and mature concrete with fly ash additive. Solid State Phenom. 2016, 254, 120-125. [CrossRef]

34. Shen, Y.; Huang, J.; Ma, X.; Hao, F.; Lv, J. Experimental study on the free shrinkage of lightweight polymer concrete incorporating waste rubber powder and ceramsite. Compos. Struct. 2020, 242, 112152. [CrossRef]

35. Song, H.; Fan, H.; Gao, H.-T.; Liu, J.-A.; Mou, H. Improving fly ash brightness with carbon and iron oxide removal. Recycling 2020, 5, 5. [CrossRef]

36. Afkhami, B.; Akbarian, B.; Beheshti, N.; Kakaee, A.H.; Shabani, B. Energy consumption assessment in a cement production plant. Sustain. Energy Technol. Assess. 2015, 10, 84-89. [CrossRef] 
37. Huntzinger, D.N.; Eatmon, T.D. A life-cycle assessment of Portland cement manufacturing: Comparing the traditional process with alternative technologies. J. Clean. Prod. 2009, 17, 668-675. [CrossRef]

38. Mikulcic, H.; Vujanovic, M.; Markovska, N.; Filkoski, R.V.; Ban, M.; Duic, N. $\mathrm{CO}_{2}$ emission reduction in the cement industry. Chem. Eng. Trans. 2013, 35, 703-708.

39. Ali, M.B.; Saidur, R.; Hossain, M.S. A review on emission analysis in cement industries. Renew. Sustain. Energy Rev. 2011, 15, 2252-2261. [CrossRef]

40. Madlool, N.A.; Saidur, R.; Hossain, M.S.; Rahim, N.A. A critical review on energy use and savings in the cement industries. Renew. Sustain. Energy Rev. 2011, 15, 2042-2060. [CrossRef]

41. Deja, J.; Uliasz-Bochenczyk, A.; Mokrzycki, E. $\mathrm{CO}_{2}$ emissions from Polish cement industry. Int. J. Greenh. Gas Control 2010, 4, 583-588. [CrossRef]

42. Gielen, D.; Taylor, P. Indicators for industrial energy efficiency in India. Energy 2009, 34, 962-969. [CrossRef]

43. Mikulcic, H.; Vujanovic, M.; Duic, N. Reducing the $\mathrm{CO}_{2}$ emissions in Croatian cement industry. Appl. Energy Prod. 2013, 101, 41-48. [CrossRef]

44. Atmaca, A.; Yumrutas, R. Analysis of the parameters effecting energy consumption of a rotary kiln in cement industry. Appl. Therm. Eng. 2014, 66, 435-444. [CrossRef]

45. Radwan, A.M. Different possible ways for saving energy in the cement production. Adv. Appl. Sci. Res. 2012, 3, 1162-1174.

46. Mikulcic, H.; Vujanovic, M.; Duic, N. Improving the sustainability of cement production by using numerical simulation of limestone thermal degradation and pulverized coal combustion in a cement calciner. J. Clean. Prod. 2015, 88, 262-271. [CrossRef]

47. Grillo Reno, M.L.; Ferrari Alves, L.F.; Escobar Palacio, J.C.; Souza, L.; Centeno González, F.O.; Pacheco Torres, P.J. Environmental analyze of cement production with application of wastes. Engevista 2017, 19, 916-930. [CrossRef]

48. Ali, N.; Jaffar, A.; Anwer, M.; Khurram, S.; Alwi, K.; Muhammad; Anjum, M.N.; Ali, N.; Muhammad, R.; Raja; et al. The greenhouse gas emissions produced by cement production and its impact on environment: A review of global cement processing. Int. J. Res. 2015, 2, 488-500.

49. Benehelal, E.; Zahedi, G.; Shamsaei, E.; Bahadori, A. Global strategies and potentials to curb $\mathrm{CO}_{2}$ emissions in cement industry. J. Clean. Prod. 2013, 51, 142-161. [CrossRef]

50. Long, G.; Gao, Y.; Xie, Y. Designing more sustainable and greener self-compacting concrete. Constr. Build. Mater. 2015, 84, 301-306. [CrossRef]

51. Golewski, G.; Sadowski, T. Fracture toughness at shear (mode II) of concretes made of natural and broken aggregates. Brittle Matrix Compos. 2006, 8, 537-546.

52. Golewski, G.L.; Sadowski, T. Macroscopic evaluation of fracture processes in fly ash concrete. Solid State Phenom. 2016, 254, 188-193. [CrossRef]

53. Golewski, G.L.; Sadowski, T. Experimental investigation and numerical modeling fracture processes in fly ash concrete at early age. Solid State Phenom. 2012, 188, 158-163. [CrossRef]

54. Jin, R.; Chen, Q.; Soboyejo, A. Survey of the current status of sustainable concrete production in the U.S. Resour. Conser. Recycl. 2015, 105, 148-159. [CrossRef]

55. Imounga, H.M.; Bastidas-Arteaga, E.; Pitti, R.M.; Ango, S.E.; Wang, X.-H. Bayesian assessment of the effects of cyclic lods on the chloride ingress process into reinforced concrete. Appl. Sci. 2020, 10, 2040. [CrossRef]

56. Atsonios, K.; Grammelis, P.; Antiohos, S.K.; Nikolopoulos, N.; Kakaras, E.M. Interation of calcium looping technology in existing cement plant for $\mathrm{CO}_{2}$ capture: Process modeling and technical considerations. Fuel 2015, 153, 210-223. [CrossRef]

57. Mikulcic, H.; Vujanovic, M.; Fidaros, D.K.; Priesching, P.; Minic, I.; Tatschl, R.; Duic, N.; Stefanović, G. The application of CFD modelling to support the reduction of $\mathrm{CO}_{2}$ emissions in cement industry. Energy 2012, 45, 264-473. [CrossRef]

58. Mokrzycki, E.; Uliasz-Bocheńczyk, A. Alternative fuels for the cement industry. Appl. Energy 2003, 74, 95-100. [CrossRef]

59. Mokrzycki, E.; Uliasz-Bocheńczyk, A.; Sarna, M. Use of alternative fuels in the Polish cement industry. Appl. Energy 2003, 74, 101-111. [CrossRef]

60. Kääntee, U.; Zevenhoven, R.; Backman, R.; Hupa, M. Cement manufacturing using alternative fuels and the advantages of process modelling. Fuel Process. Technol. 2004, 85, 293-301. [CrossRef] 
61. Chatziaras, N.; Psomopoulos, C.S.; Themelis, N.J. Use of alternative fuels in cement industry. In Proceedings of the 12th International Conference on Protection and Restoration of the Environment, Skiathos Island, Greece, 29 June-3 July 2014; pp. 521-529.

62. Mikulcic, H.; Klemes, J.J.; Vujanovic, M.; Urbaniec, K.; Duic, N. Reducing greenhouse gasses emissions by fostering the deployment of alternative raw materials and energy sources in the cleaner cement manufacturing process. J. Clean. Prod. 2016, 136, 119-132. [CrossRef]

63. Golewski, G.L. Determination of fracture toughness in concretes containing siliceous fly ash during mode III loading. Struct. Eng. Mech. 2017, 62,1-9. [CrossRef]

64. Golewski, G.L. Effect of fly ash addition on the fracture toughness of plain concrete at third model of fracture. J. Civ. Eng. Manag. 2017, 23, 613-620. [CrossRef]

65. Golewski, G.L. Measurement of fracture mechanics parameters of concrete containing fly ash thanks to use of Digital Image Correlation (DIC) method. Measurement 2019, 135, 96-105. [CrossRef]

66. Malhotra, V.M. Reducing $\mathrm{CO}_{2}$ emissions. Concr. Int. 2006, 28, 42-45.

67. Li, H.; Sun, H.; Tian, J.; Yang, Q.; Wan, Q. Mechanical and ultraconic testing of self-compacting concrete. Energies 2019, 12, 2187. [CrossRef]

68. Li, H.; Sun, H.; Zhang, W.; Gou, H.; Yang, Q. Study on mechanical properties of self-compacting concrete and its filled in-line multi-cavity steel tube bundle shear wall. Energies 2019, 12, 3466. [CrossRef]

69. Parzenny, H.R.; Róg, L. Distribution of some ecotoxic elements in fuel and solid combustion residues in Poland. Energies 2020, 13, 1131. [CrossRef]

70. Aprianti, S.E. A huge number of artificial waste material can be supplementary cementitious material (SCM) for concrete production-A review part II. J. Clean. Prod. 2017, 142, 4178-4194. [CrossRef]

71. Golewski, G.L. Studies of natural radioactivity of concrete with siliceous fly ash addition. Cem. Wapno Beton 2015, 2, 106-114.

72. Xie, T.; Visitin, P. A unified approach for mix design of concrete containing supplementary cementitious materials based on reactivity moduli. J. Clean. Prod. 2018, 203, 68-82. [CrossRef]

73. Xie, T.; Yang, G.; Zhao, X.; Xu, J.; Fang, C. A unified model for predicting the compressive strength of recycled aggregate concrete containing supplementary cementitious materials. J. Clean. Prod. 2020, 251, 119752. [CrossRef]

74. Carevi, I.; Serdar, M.; Stirmer, N.; Ukrainczyk, N. Preliminary screening of wood biomass ashes for partial resources replacements in cementitious materials. J. Clean. Prod. 2019, 229, 1054-1064. [CrossRef]

75. Turner, L.K.; Collins, F.G. Carbon dioxide equivalent $\left(\mathrm{CO}_{2}\right.$-e) emissions: A comparison between geopolymer and OPC cement concrete. Constr. Build. Mater. 2013, 43, 125-130. [CrossRef]

76. Golewski, G.L. An assessment of microcracks in the Interfacial Transition Zone of durable concrete composites with fly ash additives. Compos. Struct. 2018, 200, 515-520. [CrossRef]

77. Sobolev, K.; Ferrada-Gutierrez, M. How nanotechnology can change the concrete world, Part 1. Am. Ceram. Soc. Bull. 2005, 84, 14-17.

78. Horszczaruk, E. Role of nanosiloca in the formation of the properties of cement composites, state of the art. Cem. Wapno Beton. 2018, 6, 487-495.

79. Raki, L.; Beaudoin, J.; Aizadeh, R.; Makar, J.; Sato, T. Cement and concrete nanoscience and nanotechnology. Materials 2010, 3, 918-942. [CrossRef]

80. Szostak, B.; Golewski, G.L. Effect of nano admixture of CSH on selected strength parameters of concrete including fly ash. IOP Conf. Ser. Mater. Sci. Eng. 2018, 416, 012105. [CrossRef]

81. Szymanowski, J.; Sadowski, L. The development of nanoalumina-based cement mortars for overlay applications in concrete floors. Materials 2019, 12, 3465. [CrossRef]

82. Giergiczny, Z. Fly ash and slag. Cem. Concr. Res. 2019, 124, 105826. [CrossRef]

83. Li, Y.; Fu, T.; Wang, R.; Li, Y. An assessment of microcracks in the interfacial transition zone of recycled concrete aggregates cured by $\mathrm{CO}_{2}$. Constr. Build. Mater. 2020, 236, 117543. [CrossRef]

84. Zhang, R.; Guo, F.; Xia, Y.; Tan, J.; Xing, Y.; Gui, X. Recovering unburned carbon from gasification fly ash using saline water. Waste Manag. 2019, 98, 29-36. [CrossRef] [PubMed]

85. Zhang, P.; Li, Q.; Chen, Y.; Shi, Y.; Ling, Y.-F. Durability of steel fiber-reinforced concrete containing $\mathrm{SiO}_{2}$ nano-particles. Materials 2019, 12, 2184. [CrossRef] [PubMed]

86. Hemalatha, T.; Ramaswamy, A. A review on fly ash characteristics-Towards promoting high volume utilization in developing sustainable concrete. J. Clean. Prod. 2017, 147, 546-559. [CrossRef] 
87. Gil, D.M.; Golewski, G.L. Effect of silica fume and siliceous fly ash addition on the fracture toughness of plain concrete in mode I. IOP Conf. Ser. Mater. Sci. Eng. 2018, 416, 012065. [CrossRef]

88. Blissett, R.S.; Rowson, N.A. A review of the multi-component utilization of coal fly ash. Fuel 2012, 97, 1-23. [CrossRef]

89. Gil, D.M.; Golewski, G.L. Potential of siliceous fly ash and silica fume as a substitute of binder in cementitious concrete. E3S Web Conf. 2018, 49, 00030. [CrossRef]

90. Zeng, S.; Wang, J. Characterization of mechanical and electric properties of geopolymers synthesized using four locally available fly ashes. Constr. Build. Mater. 2016, 121, 386-399. [CrossRef]

91. Golewski, G.L. The influence of microcrack width on the mechanical parameters in concrete with the addition of fly ash: Consideration of technological and economical benefit. Constr. Build. Mater. 2019, 197, 849-861. [CrossRef]

92. Golewski, G.L. Generalized fracture toughness and compressive strength of sustainable concrete including low calcium fly ash. Materials 2017, 10, 1393. [CrossRef]

93. Golewski, G.L. An analysis of fracture toughness in concrete with fly ash addition, considering all models of cracking. IOP Conf. Ser. Mater. Sci. Eng. 2018, 416, 012029. [CrossRef]

94. Fuzail Hashmi, A.; Shariq, M.; Baqi, A.; Haq, M. Optimization of fly ash concrete mix-A solution for sustainable development. Mater. Today Proc. 2020. [CrossRef]

95. Golewski, G.L. Effect of curing time on the fracture toughness of fly ash concrete composites. Compos. Struct. 2018, 185, 105-112. [CrossRef]

96. Zhang, P.; Wan, J.; Wang, K.; Li, Q. Influence of nano-SiO ${ }_{2}$ on properties of fresh and hardened high performance concrete: A state-of-the-art review. Constr. Build. Mater. 2017, 148, 648-658. [CrossRef]

97. Ling, Y.; Zhang, P.; Wang, J.; Chen, Y. Effect of PVA fiber on mechanical properties of cementitious composite with and without nano-SiO ${ }_{2}$. Constr. Build. Mater. 2019, 229, 117068. [CrossRef]

98. Zhang, P.; Gao, J.-X.; Dai, X.-B.; Zhang, T.-H. Fracture behavior of fly ash concrete containing silica fume. Struct. Eng. Mech. 2016, 59, 261-275. [CrossRef]

99. Biricik, H.; Sarier, N. Comparative study of the characteristics of nanosilica-, silica fume- and fly ash-incorporated cement mortars. Mater. Res. 2014, 17, 570-582. [CrossRef]

100. More, S.; Londhe, R.S. Experimental analysis of quaternary cement binder. Recent Trends Civ. Eng. Technol. 2020, 10, 12-17.

101. Pipilikaki, P.; Katsioti, M. Study of the hydration process of quaternary blended cements and durability of the produced mortars and concretes. Constr. Build. Mater. 2009, 23, 2246-2250. [CrossRef]

102. El-Chabib, H.; Ibrahim, A. The performance of high-strength flowable concrete made with binary, ternary, or quaternary binder in hot climate. Constr. Build. Mater. 2013, 47, 245-253. [CrossRef]

103. Dave, N.; Misra, A.K.; Srivastava, A.; Sharma, A.K.; Kaushik, S.K. Study on quaternary micro-structure, strength, durability considering the influence of multi-factors. Constr. Build. Mater. 2017, 139, 447-457. [CrossRef]

104. Dave, N.; Misra, A.K.; Srivastava, A.; Kaushik, S.K. Setting time and standard consistency of quaternary binders: The influence of cementitious material addition and mixing. Int. J. Sustain. Built Environ. 2017, 6, 30-36. [CrossRef]

105. Dave, N.; Misra, A.K.; Srivastava, A.; Kaushik, S.K. Experimental analysis of strength and durability properties of quaternary cement binder and mortar. Constr. Build. Mater. 2016, 107, 117-124. [CrossRef]

106. Dave, N.; Misra, A.K.; Srivastava, A.; Sharma, A.K.; Kaushik, S.K. Green quaternary concrete composites: Characterization and evaluation of the mechanical properties. Struct. Concr. 2018, 19, 1280-1289. [CrossRef]

107. Dhrangadharia, S.; Vishwakarma, S.; Kumar, A.; Saran, B. Effect of quaternary binders systems on mechanical properties of concrete. Int. J. Eng. Sci. Res. 2018, 6, 1-10.

108. Manju, R.; Premalatha, J. Binary, ternary and quaternary effect of pozzolanic binders and filler materials on the properties of self compacting concrete (SCC). Int. J. Adv. Eng. Technol. 2016, 7, 674-683.

109. Manju, R.; Premalatha, J. Binary, ternary and quaternary effect of fillers on fresh and hardened properties of self compacting concrete (SCC). Int. J. Adv. Inf. Sci. Technol. 2014, 21, 12-19.

110. Karim, M.R.; Zain, M.F.M.; Jamil, M.; Lai, F.C. Development of a zero-cement binder using slag, fly ash, and rice husk ash with chemical activator. Adv. Mater. Sci. Eng. 2015, 247065. [CrossRef]

111. Patel, N.; Dave, R.; Modi, S.; Joshi, C.; Vora, S.; Solanki, M. Effect of binary and quaternary blends on compressive strength. Int. J. Civ. Eng. Technol. 2016, 7, 242-246. 
112. Bassuoni, M.T.; Nehdi, M.L. Resistance of self-consolidating concrete of sulfuric acid attack with consecutive pH reduction. Cem. Concr. Res. 2007, 37, 1070-1084. [CrossRef]

113. Chinnaraju, K.; Subramanian, K.; Senthil Kumar, S.R.R. Strength properties of HPC using binary, ternary and quaternary cementitious blends. Struct. Concr. 2010, 11, 191-198. [CrossRef]

114. EN 197-1:2011. Cement-Part 1: Composition, Specifications and Conformity Criteria For Common Cements; NSAI Standard: Dublin, Ireland, 2011.

115. EN 12390-3:2011+AC:2012. Testing Hardened Concrete-Part 3: Compressive Strength of Test Specimens; British Standards Institution (BSI): London, UK, 2012.

116. EN 12390-6:2009. Testing Hardened Concrete-Part 6: Tensile Splitting Strenght of Test Specimens; British Standards Institution (BSI): London, UK, 2009.

117. Vassilev, S.V.; Vassileva, C.G. Methods for characterization of composition of fly ashes from coal-fired power stations: A critical overview. Energy Fuels 2005, 19, 1084-1098. [CrossRef]

118. Bicer, A. Effect of production temperature on thermal and mechanical properties of polystyrene-fly ash composites. Adv. Compos. Lett. 2020, 29, 1-8. [CrossRef]

119. Sadowski, T.; Golewski, G.L. A failure analysis of concrete composites incorporating fly ash during torsional loading. Compos. Struct. 2018, 183, 527-535. [CrossRef]

120. Golewski, G.L. A novel specific requirements for materials used in reinforced concrete composites subjected to dynamic loads. Compos. Struct. 2019, 223, 110939. [CrossRef]

121. Golewski, G.L. A new principles for implementation and operation of foundations for machines: A review of recent advances. Struct. Eng. Mech. 2019, 71, 317-327.

122. Niewiadomski, P.; Hoła, J.; Ćwirzeń, A. Study on properties of self-compacting concrete modified with nanoparticles. Arch. Civ. Mech. Eng. 2018, 18, 877-886. [CrossRef]

(C) 2020 by the author. Licensee MDPI, Basel, Switzerland. This article is an open access article distributed under the terms and conditions of the Creative Commons Attribution (CC BY) license (http://creativecommons.org/licenses/by/4.0/). 